\title{
PERCEIVED TOURISM IMPACTS IN PINDUL CAVE, YOGYAKARTA, INDONESIA
}

\author{
Musadad. \\ Universitas Riau \\ sadad.sanusi@gmail.com
}

\begin{abstract}
Gunungkidul Regency, Yogyakarta Province, Indonesia is experiencing significant increase in its visitors due to the massive development of its tourism objects, especially natural ones such as caves and beaches. Pindul Cave is one of the most prominent tourism object in Gunungkidul which is also visited by a high number of tourists although it was just opened in the late 2011s. Therefore, by conducting interviews with locals and the management as well as observation to collect data, this study investigated the perceived impacts of tourism in Pindul Cave. The analysis results show that the residents have positive attitudes towards socio-cultural, economic, and environmental impact although they also perceive negative impacts such as the way of employee's recruitment by the management and the degradation of environment in the cave. However, these negative impacts are perceived minor by the residents so that, overall, they perceive that the development of tourism in Pindul Cave is positive.
\end{abstract}

Keywords: CBT, Local Community, Tourism Impact, Pindul Cave, Yogyakarta, Indonesia

\section{Introduction}

Over the past five years, Gunungkidul, one of regencies in Yogyakarta Special Region, has shown increasing number of tourists. This phenomenon cannot be separated from the development of new natural tourist objects like beaches and caves. This regency has been promoting and developing new tourism objects since 2010s. The visitors tend to be attracted by the natural ones since this regency is well-known of its natural beaches. Significant increase in the number of visitors in Gunungkidul Regency also proves that todays' tourists tend to choose natural attractions. Below is the data of the number of tourist visits to Gunungkidul Regency from 2010-2013. 
Table 1

Tourist Arrivals to Gunungkidul Regency from 2010-2014

\begin{tabular}{|l|l|l|l|l|}
\hline \multirow{2}{*}{ No. } & \multirow{2}{*}{ Year } & Tourists & \multicolumn{3}{|l|}{} \\
\cline { 3 - 5 } & & Foreign & Local & Total \\
\hline 1. & 2010 & - & 488,805 & 488,805 \\
\hline 2. & 2011 & - & 688,405 & 688,405 \\
\hline 3. & 2012 & 2,053 & $1,277,012$ & $1,279,065$ \\
\hline 4. & 2013 & 3,558 & $1,818,693$ & $1,822,251$ \\
\hline 5. & 2014 & 5,319 & $3,679,818$ & $3,685,137$ \\
\hline
\end{tabular}

Source: Statistik Kepariwisataan 2014 (2015)

Table 1 shows that the number of tourists visiting Gunungkidul increases significantly from 2010-2014. This suggests that the tourists prefer natural objects as the regency offers mainly natural objects in addition to cultural ones.

One of the most prominent tourist objects in Gunungkidul that is very popular because of its unique attraction is Pindul Cave. The cave which is located in the village of Bejiharjo, Karangmojo Sub-District, Gunungkidul offers an exotic landscape, coupled with a main attraction of exploring the cave using a tube so that this attraction is called cavetubing. This attraction is very popular among tourists coming to Yogyakarta.

Table 2

The Number of Tourists in Pindul Cave in 2014

\begin{tabular}{|l|l|l|}
\hline \multicolumn{3}{|l|}{ Tourists } \\
\hline Foreign & Local & Total \\
\hline 3,533 & 426,413 & 429,946 \\
\hline
\end{tabular}

Source: Statistik Kepariwisataan 2014 (2015)

Table 2 shows the number of tourists in Pindul Cave in 2014. For an object like the cave which was just opened in the late 2011, the number is great.

Not only popular with the high number of tourists, Pindul Cave is popular with the conflict. At least there are two conflicts which are blown up by the media: conflict over ownership of land and conflict among managements.

One of the interesting things in Pindul Cave is that the tourism activities are managed by the local community. This is one aspect that is very clearly visible in the application of the concept of community-based tourism (CBT). Local participation is important because one of the keys to successful CBT is the involvement of local community (Timothy, 1999:372).

Taking into account the CBT, the high number of visitors in Pindul Cave and tourism conflict, a scientific study on the impacts of tourism activities in Pindul Cave is, therefore, necessary to do. Therefore, this study was aimed to identify the perceived impacts of tourism in Pindul Cave.

\section{Literature Review}

This section presents some concepts related to community-based tourism and tourism impact. 


\section{Community-Based Tourism}

The community-based tourism (CBT) approach emerged in the 1970s and was influenced by two main factors. First, an increased recognition that tourism development was not benign and had negative socio-cultural, economic, and environmental impacts on some members of destination communities. Second, a realization in urban or regional planning that the community stakeholders often needed to be involved in decision-making if planning interventions were to be successful (Cooper and Hall, 2008: 200).

In addition to issues related to the success of a program/project in tourism, CBT is also very closely related to the issue of sustainable tourism. A development including tourism needs sustainability concept for the sake of its continuity, not only for the moment. Community-based tourism, according Häusler and Strasdas (2002:1), has multiple definitions:

1) $\mathrm{CBT}$ is a form of tourism that provides the opportunity for local communities to control and be involved in the management and development of tourism;

2) Communities who are not directly involved in tourism can also receive its benefits; and

3) CBT requires political empowerment, democratization, and distribution of benefits to disadvantaged communities in rural areas.

\section{Tourism Impact}

This study investigated the perceived impacts (attitudes or opinion of local community towards tourism development in their area) rather than analyzing the actual impacts (such as real income or actual environmental degradation). Generally, there are three types of impact in the tourism activities; economic, socio-cultural and environmental impact (Hall \& Lew, 2009).

\section{Economic Impact}

The net economic benefit of tourism in the Livingstone area is mainly positive in regards to increased government earnings, job creation, infrastructure and macroeconomic stability ("Economic impacts of tourism," 2009). In case of direct impact, the owners and employees in tourism businesses gain directly from the tourism industry. Indirectly, many more people gain their income (partly) from the tourism industry (Telfer \& Sharpley, 2008).

Socio-cultural Impact

Enemuo et al (2012) proved that tourism development had significant effect on the social lives of the host communities and tourism development had significant effect on the sustainability of the socio-cultural lives of the host communities. The tourism industry may empower marginalized groups, such as women or indigenous people, through employment and cultural connections (Scheyvens, 2002). However, some negative social impacts include increase of crime and sex tourism, while in case of culture, tourism may bring negative impacts such as degradation of sacred places or rituals (Hall \& Lew, 2009).

\section{Environmental impact}

The negative impacts of tourism development can gradually destroy environmental resources on which it depends, but on the other hand, tourism has the potential to create beneficial effects on the environment by contributing to environmental protection and conservation (Sunlu, 2003). Mowforth \& Munt 
(2003) argues that the growth of mass tourism has led to a range of problems, which have become more obvious over the recent years. It includes environmental, social and cultural poverty.

\section{Methodology}

This study focused on the residents living in Gelaran II Hamlet. This hamlet was selected among another 20 hamlets in the village of Bejiharjo (study population) considering that Pindul Cave is geographically located in this hamlet. In addition, this hamlet has a tourism management (namely Wira Wisata) whose focus of tourism development/attraction is Pindul Cave itself - some other managements have another attractions such Suci River and Oyo River.

\section{Data Collection}

By focusing on Gelaran II Hamlet, Bejiharjo Village, Karangmojo Sub-District, Gunungkidul, this study employed a qualitative approach. The data was collected through interviews, document review, and observation. Interviews were conducted with locals, hamlet's head and the management of Pindul Cave. Document review was conducted to gain secondary data, including data on number of visitors, amount of income, etc. Lastly, the observation was conducted to find out the real view of tourism impact.

\section{Data Analysis}

In qualitative research, data analysis essentially involves preparing and organizing the data (i.e. text data as in transcripts, or image data as in photographs) for analysis, then reducing the data into themes through a process of coding and condensing the codes, and finally presenting the data in figures, tables, or a discussion (Creswell, 2013).

The data was analyzed inductively, i.e. starting from the field or empirical facts, and then studying the phenomena existing in the field. Because using inductive reasoning, then the hypothesis formulation is not required. Inductive analysis, according to Miles and Huberman (1984) includes data reduction, data display, and decision-making or verification.

\section{Results and Discussion}

In general, it is understandable that the development of tourism has an impact on local community. The focus of this study is on the impact of tourism on the local level, or more specifically the perceived tourism impact. This study did not analyze the actual impact indicators such as real income or actual environmental degradation, but focused on the attitude (opinion) of local community towards the development of tourism in their area.

\section{Socio-Cultural Impact}

As we know, tourism can have much impact on the local community, especially when it concerns with a small community with a high volume of tourist visits. Event in Gelaran II Hamlet, tourism is well managed as an ideal example for small scale positive and negative social impact. Fortunately, the positive impact is more dominant (major) than the negative one. The results of interviews 
show that the population has a positive attitude towards the existing tourism activities in their area.

One positive impact which is often admitted by locals is that tourism leads to the revival of local culture. For example, a traditional dance performed for tourists. They usually perform Jathilan and Gejog Lesung dances. In addition, traditional music as Karawitan is also often performed for tourists. The tourists are interested in such traditional arts and the locals also enjoy performing them, winwin situation (both tourists and local residents gain benefit alike).

In addition to traditional arts, the revival of traditional culture is also evident from the practice of traditional ceremony/ritual. Unlike traditional arts that are deliberately performed for the purpose of tourism (entertainment), traditional rituals such as Rasulan and Tumpengan are not directly related to the tourism activity. It is because before and after the tourism development of Pindul Cave, people have already practiced such traditional rituals. But the difference is that after the tourism development of Pindul Cave, the frequency and enthusiasm of residents to organize such activities are increasing. It cannot be separated from the economic benefits received by the people, which have contributed to financing such costly rituals. The revival of the local rituals/ceremonies, in addition to be driven by the fund supply as a result of tourism activities, is also directly associated with the public expression of gratitude for the presence of tourism in Pindul Cave which has brought positive impacts on their lives.

The results of interviews with the residents confirm that tourism promotes pride in local culture, as well as the restoration and conservation of culture. In addition, tourism activities in Gelaran II Hamlet unite the residents. The residents admit that the revival of the old tradition (ceremony/ritual) make them closer (more cohesive). Traditional dance performance, for example, is a good opportunity for locals to come and gather. Unity and cohesion of residents are also caused by the intensity of their interaction as a result of frequent and regular meetings (like a RT/RW or PKK meetings) which are held directly or indirectly to discuss tourism activities because usually they will gather and discuss tourism in Pindul Cave in those meetings. However, the development of tourism in Pindul Cave has caused disharmony among tourism managements, or in the village scale.

Tourism has generated education in Gelaran II Hamlet in various ways. It is not always limited to the members of the community or the tourism industry alone. At first, the education was intended specifically for community as actors of CBT in terms of tourism development conducted by educational institution or government, but then the management also provides education for the children of the community members by establishing early childhood education (PAUD) and private lessons for primary and junior high school children. The management also provides and pays teachers who are from local youths who are college graduates. This educational activity is held in the Joglo (Javanese Hall) of Wira Wisata Management Secretariat. In addition, the residents also receive training/education on reforestation and diversification of their agricultural land. According to them, this is not possible if there is no tourism development in their area.

Another social change in the community that may not be entirely due to the development of tourism is that women in Gelaran II Hamlet get a considerable role in the development of tourism. Apart from their limited role, e.g. cooking and preparing all stuffs for receiving guests, they are now involved in planning the 
homestay. They usually engage in dialogues with the management concerning the furniture, dishes, and others associated with the homestay. Until now, there have been 30 homestays in Gelaran II Hamlet, which are managed independently by the residents.

Lastly, it is of interest related to the social impact of tourism in Pindul Cave, i.e. tourism can reduce or even eliminate juvenile delinquency. As revealed by many residents as well as the head of the hamlet, in the past the youths often hung-out with no productive activities so that there were usually negative activities. All change with the development of tourism in their village. This phenomenon is not surprising because the boys are currently busy with a variety of tourist activities (e.g. working as staffs), and they realize if they keep doing bad behaviors, it will disturb the comfort of tourists and create bad image of tourism in their hamlet.

Overall, this study suggests that the residents have a very positive attitude towards the social impact of tourism in their hamlet. It is undeniable that there are also negative social impacts that create small friction in communities, i.e. the discontent of citizens over the means of recruitment for work in the Secretariat of Wira Wisata Management. However it is very minor when compared to the positive impact because the number of those who are not satisfied is very low and can be overcome by the management through various community empowerment programs such as providing incentive for the poor, the elderly, the disabled, and widows with a nominal ranging from IDR 100,000 to IDR 200,000 per month. In addition, in health program, the management provides a free 24-hour transportation for those who want to go to hospital. In education program, the management establishes and organizes free 'early childhood education' (PAUD) and free private lessons for elementary and junior high school children.

\section{Economic impact}

The economic impact of tourism in Pindul Cave is generally very high. The most obvious impact is the creation of jobs and additional income. Even most people who are asked about their income from the tourism sector admit that working in Pindul Cave tourism is their main income, not an additional income. In Wira Wisata Management, they usually work as guides, administrative staffs and food vendors. There are only a few who work in tourism activity as their side jobs such as being parking attendants, cooking (catering), and selling snacks.

For most of those whose houses are served as homestays, tourism creates only a small percentage of their income. However, this little extra income confirms that they at least have some income during a period when they do not get income from their work in the fields (harvesting crops). Tourism, in this way, creates other possibilities to earn money, and make people less dependent on harvesting crops.

The guides are employees who enjoy very much the economic benefit of tourism in Pindul cave. Many residents want to become a guide, especially men. It is very reasonable considering each guide will receive a fee of IDR 30,000 per trip. Every day, they can guide visitors 2-3 times in the low season, but in the high season it can be 6-7 times. In the low season, their income is 3 trip x IDR 30,000 $=$ IDR 90,000 per day, while in the high season, they can get $7 \times$ IDR 30,000= IDR 210,000 per day. If we take an average of four trips a day, then IDR $4 \mathrm{x}$ 
$30,000=$ IDR 120,000 per day. So, within 1 month they can get IDR 120,000 x 30 $=$ IDR 3,600,000. This nominal can be said to be a very high increase in income compared to when they work as agricultural labors or construction workers with an average salary of only IDR 800,000 per month. Hence, it is now not surprising, since there so many people working in Pindul Cave, it is difficult for the residents of Bejiharjo themselves to find laborers (construction /agricultural) from their own village. Therefore, those who need workers must seek to another villages. In addition, residents, especially the youth, who used to wander out of the region as laborers or food (bakso) sellers, eventually return to their village to work in Pindul Cave.

In addition to those working directly for tourists as homestay members or guides, there are also other businesses that gain benefit from tourism. Local stall owners, for example, get a lot of tourists as buyers and even they sell some products to tourists. In addition, many jobs are available such as being parking attendants, renting parking lots and restrooms, and others.

In term of socio-economic impact, the standard of living in the Gelaran II Hamlet changes a little bit because of tourism. This is seen especially in the maintenance of houses. Due to the development of tourism with its economic benefits, the residents often repair their houses like re-painting, making ceramic floors, or other construction works. This is also related to the homestay standard that has been agreed together. This type of investment is usually carried out by the families whereby they sometimes receive money from the management to improve the quality of their homestays for the convenience of visitors/guests. The improvement in living standard usually occurs in an exclusive group (owners of the homestay) that the gap between the residents tends to increase.

\section{Environmental impact}

The residents of Gelaran II Hamlet have mostly been exposed to the positive environmental impact of the development of tourism in Pindul Cave. The most obvious one is the residents really see that the streets in their village has become much cleaner and neater because of the tourists coming to visit. The residents keep their village clean. The management has also provided three dumpsters in which the trash are transported every month. Tourism in this case, therefore, provides good motivation to improve the environment.

Not only clean and orderly environment, but the forest around the village is also conserved and planted again. To manage this program, the Wira Wisata management intentionally collaborates with the Sedyomulyo farmer group in Gelaran II Hamlet. Previously, it is usual that the local residents cut the tress for wood. Because the tourism industry has been growing and the residents have received training, they are now more aware of the importance of nature conservation.

In the cave, however, is more difficult to eliminate the negative impact of tourism development. A guide explained that tourism has caused damage to the cave. Stalactite or stalagmite may be damaged due to human's touch because the rocks will be dead or at least stop growing. Besides endangering the stalactites or stalagmites, tourism has eliminated nearly $75 \%$ of animals living in the cave like bats and fish. The guide said, before the development of tourism, Pindul Cave is home to three species of bats and various types of freshwater fish. But now the 
number is reduced drastically. Thus, tourism will always be dangerous for the cave, but the efforts made to overcome this negative effect is still low.

In relation to the environmental impact of tourism, Häusler and Strasdas (2002:9) warns that rapid development, over-development, and overcrowding can forever change the physical environment and ecosystems of an area; sensitive areas and habitat may be lost. It is because one of the negative impacts of CBT on the environment is the over-use of natural resources. Even, what happens in Pindul Cave is no longer 'rapid development' but already at the level of 'overcrowding'. Therefore, a firm and decisive handling to save the tourist object from absolute severe damage must be realized.

\section{Conclusions}

This study concluded that the residents of Gelaran II Hamlet perceive that the development of tourism in Pindul Cave is positive. Their positive attitudes towards tourism development in their area are mainly driven by the high economic benefit they get from the tourism activities. Although there are some negative impacts such as discontent over the way the management recruit employees and degradation of environment in the cave, the development of tourism in the cave is still perceived as positive.

\section{REFERENCES}

Cooper, C. and Hall, C. M. (2008). Contemporary Tourism: an International Approach. Oxford: Butterworth-Heinemann.

Creswell, J. W. (2013). Qualitative Inquiry and Research Design: Choosing among Five Approaches (3rd ed). Los Angeles: SAGE Publication.

Enemuo, et al. (2012). Social Impact of Tourism Development on Host Communities of Osun Oshogbo Sacred Grove. Journal of Humanities and Social Science. 2(6), 30-35

Hall, M. C., \& Lew, A. A. (2009). Understanding and managing tourism impacts: An integrated approach. New York: Routledge.

Häusler, N. \& Wolfgang, S. (2002). Training Manual for Community-based Tourism. Leipzig: InWent.

Economic impacts of tourism in the Livingstone area, Zambia. (2009). Retrieved June 22, 2016 from Lion Alert Website, lionalert.org/documents/FRSPublications/Doppelmayr_2009.pdf

Miles, M. B. \& Huberman, A. M. (1984). Qualitative Data Analysis: A Sourcebook of New Methods. California: SAGE Publications Inc.

Mowforth, M. and Munt, I. (2003). Tourism and Sustainability: Development and New Tourism in the Third World. New York: Routledge. 
Telfer, D. J., \& Sharpley, R. (2008). Tourism and development in the developing world. New York: Routledge.

Scheyvens, R. (2002). Tourism for development: empowering communities. Harlow: Pearson Education Limited.

Statistik Kepariwisataan 2014. (2015). Dinas Pariwisata Yogyakarta

Sunlu, U. (2003). Environmental impacts of tourism in Camarda D. (ed.), Grassini L. (ed.). Local resources and global trades: Environments and agriculture in the Mediterranean region. Bari: CIHEAM, 263-270

Timothy, D.J. (1999). Participatory Planning a View of Tourism in Indonesia. Annuals Review of Tourism Research, 26(2) 